\title{
Theoretical Perspectives and the Implementation of the BBBEE Policy Framework
}

\author{
Dr. David Pooe \\ Head of Department: Logistics, Vaal University of Technology \\ Email: pooe@vut.ac.za
}

\section{Doi:10.5901/mjss.2013.v4n14p635}

\begin{abstract}
The purpose of the paper is to provide a critique on the implementation of the Broad-based economic empowerment (BBBEE) policy framework against established theory. The critique is introduced by highlighting a brief background of the BBBEE policy framework. The first part of the paper employs theories on equality and social justice as lenses through which to look at the BBBEE policy framework. The second part of the paper considers the policy implementation literature to assess the implementation of BBBEE policy. Next, the theoretical perspectives on the self-regulatory power of the market are analysed against the BBBEE policy background. Finally, the paper questions the assertion by the South African government that it is a developmental state in view of its stance on the policy. The theories considered persuasively point to silliness of government to leave the matters of social justice and equality in the hands of the insensitive market. The paper concludes that the government cannot rely on the self-regulatory power of the market to implement what is essentially the most important economic transformation programme since 1994. In view of the aforegoing, the paper makes recommendations to the policy makers.
\end{abstract}

Keywords: Black economic empowerment, social justice, policy implementation, developmental state, self-regulatory power of the market

\section{Introduction and Background}

Systematic dispossession and disempowerment of the African majority through colonialism and apartheid policies produced extreme inequalities that resulted in deeply rooted impediments to socio-economic development in South Africa (Bundy, 1982, p.228; Feinstein, 2005, p.43). When the African National Congress (ANC) took over as the ruling party in South Africa, it determined to embark on an economic restructuring programme in order to empower those that had been historically marginalised (Hirsch, 2005, p.69). This was to be a new struggle whose main focus was to deal with the legacies of apartheid by focusing on social reconstruction, the creation of opportunities and economic restructuring (Rubushe, 2009, p.30). To meet this challenge head on, the government introduced the Black Economic Empowerment (BEE) policy (McKinley, 1998; Department of Trade \& Industry, 2007, p.9; Levin, 2011, p.252). This happened in 2003 when the South African government released the Strategy for BBBEE which not only defined broad-based BEE and the transformation imperative, but also outlined the seven elements of the broad-based scorecard. Subsequently, the BroadBased BEE Act No. 53 of 2003 was promulgated in January 2004.

Yet as an activity BEE can be traced to as early as 1993 when the Afrikaner captains of industry made deals in which white companies sold shares at huge discounts to pre-identified blacks, usually of high political profile and invited them to sit on their boards of directors. Acemoglu, Gleb and Robinson (2007) refer to this period until about the year 2000 as the Phase 1 of BEE and call it the 'Uncoordinated' phase. The period since the year 2000 saw an increasing government interest in the BEE activity which was hitherto driven by white capitalists. This period saw the creation of the BEE Commission led by Cyril Ramaphosa, later by the release of the BEE Strategy, the Act, the Codes of Good Practice, and other related pieces of legislation.

Acemoglu, Gleb and Robinson (2007) envisaged that government would play a leading role in transforming the economy that they referred to the period between the years 2000 and 2014 as the 'The Big Push to Overcome the Apartheid Legacy' phase. They predicted that this 'Big Push' phase would be followed by Phase 3, which they refer to as 'Self-Sustaining Empowerment' by which time the 'Big Push' would have largely achieved its intended purpose such that empowerment should start becoming a self-sustaining process with no need for a policy such as BBBEE to generate empowerment.

This makes the BEE project to be nearly 20 years old while the government instruments to implement BEE are 
now nearly 10 years old. These instruments include the Strategy for BBBEE, the BBBEE Act No. 53 of 2003, the Codes of Good Practice, and the Interpretative Guide to the Codes which were meant to serve as an aid to understanding and interpreting the Codes. According to the Department of Trade and Industry $(2007, p .6)$ it became necessary to adopt and implement the Codes of Good Practice for the following reasons, among others:

- Lack of uniform framework for the recognition and measurement of BEE

- Extensive delays in BEE implementation due to differences in interpretation

- Lack of underlying economic substance to many BEE transactions

- Fronting due to lack of implementation guidelines

- Very little transformation within management levels

The abovementioned reasons indicate that in 2007, some three years after the promulgation of the BBBEE Act, there were already some serious difficulties related to the implementation of BBBEE policy. Five years later in 2012, once again the government acknowledges yet more challenges relating to the implementation of the BBBEE policy. This is evident from the revised Codes of Good Practice that the Cabinet has approved for public comment. In this regard, the DTI (2012, p.1) states that "the revised Codes will enhance the implementation of BBBEE in a meaningful and sustainable manner, and that the purpose of the Codes is to assist and advise the public and private sectors in the implementation of the BBBEE Act". In the main, the revised Codes simply consolidates employment equity and management control, and by merges preferential procurement and enterprise development elements of the scorecard, thereby reducing the generic scorecard from seven to five elements. It is curious to note that the Cabinet hopes that this will result in the enhanced implementation of the BBBEE policy.

Interestingly, on the two occasions in the last ten years that government sought to improve the implementation of the BBBEE policy, the focus has mainly been on the BBBEE tool itself rather than on the artisan's hand holding the tool, as it were. On the contrary, this paper will argue that the implementation challenges of the BBBEE policy framework have to do more with the mode of its implementation and less with the merits or demerits of the instrument itself. The arguments are drawn from the extant literature on social justice, policy implementation, market-based models, and governance systems. Hence, the first part of the paper will reflect on the theory of social justice and equality vis-à-vis the BBBEEE policy. The second part of the paper will apply literature on policy implementation and relate it to BBBEE policy. The third section will discuss the self-regulatory power of the market in the context of the BBBEE policy framework. Finally, the fourth section will question the developmental state espoused by the South African government in the context of implementing a policy that is probably the most crucial at this point in time in the country. On the basis of arguments presented and theories considered, policy recommendations will be made. The next section discusses equality and social justice as rationale for the BBBEE policy framework.

\section{Equality and Social Justice and the BBBEE Policy Framework}

The Constitution of South Africa states that the Republic is both sovereign as well as democratic, having been founded on the principles of human dignity and the achievement of equality (RSA, 1996). Section 9(1) of the Constitution states that "everyone is equal before the law and has the right to equal protection and benefit of the law". However, intense debate surrounds the concept of equality. For instance, Niewenhuis (2005) argues that absolute equality between people is a theoretical abstraction that cannot be defended because the notion of absolute equality is self-contradictory. Schaar (1997, p.167) aptly sums up the paradox of inequality when he opines that 'while inequality may be the root of much that is cruel and hateful in human life, it is also the root of just about everything that is admirable and interesting.' This implies then that the concept of equality is deeply paradoxical in nature and should be examined contextually.

Niewehuis (2010, p.192) draws attention to Rawls 'difference principle' which postulates that 'practices that produce inequalities among individuals are permissible only if they work out to everyone's advantage and the positions that come with greater reward are open to all'. The author further observes that the tension between promoting the equality by eradicating past injustices and developing people is obvious. The theory of social and distributive justice helps to clarify this tension. Several related policy implications emerge from the fact that exclusion concentrates inequalities in groups. Group-based inequalities prompt mobilization and advocacy, and if they are not addressed, can lead to the proliferation of conflict and violence, especially in countries with high inequality and ethnic diversity (Stewart, 2001; Easterly, 2002).

The building blocks of social justice are recognized and entrenched in the Constitution of South Africa. The Constitutional Court explicitly endorsed the notion of social justice through the unanimous judgement in the case of Government of the Republic of South Africa v Grootboom when it pronounced that: 'The people of South Africa are 
committed to the attainment of social justice and the improvement of the quality of life for everyone' (RSA, 2001).

The theory of social justice provides 'a standard whereby the distributive aspects of the basic structure of society are to be addressed' (Rawls, 1958, p.163). Bringhouse (2002, p.183) proposes that fair equality of opportunity as well as equality of condition are two basic principles that should guide social justice. Equality of opportunity relates to the equal treatment of and according of equal rights to all people. Equality of condition provides equitable outcomes to marginalized groups by recognizing past disadvantage and the existence of structural barriers embedded in the social, economic and political system that perpetuate systemic discrimination. Social justice also entails the equal redistribution of socio-economic amenities (Gerwitz \& Gribb, 2002, p.499) while emphasising the role of the state in ensuring this redistribution (Gale, 2000, p.268). Therefore, equality of condition recognises that there are situations where the application of similar rules to unequal groups can generate unequal results.

Fundamentally, the South African Constitution adopted in 1996 advances the equality of opportunity more than it does the quality of condition, perhaps even doing so to the detriment of the latter. In other words, through the Constitution, the South African society is being organized around the values that place more importance on the equal treatment of and according of equal rights to all people and less putting equitable outcomes to marginalized groups. It is argued that the current disproportionate emphasis of the equality of opportunity over the equality of condition flowing from the Constitution may not be the best vehicle to attain social justice in South Africa. This may, in part, explain the difficulty and frustration of implementing policies that recognize past disadvantage and the existence of structural barriers embedded in the social, economic and political system that perpetuate systemic discrimination. BBBEE is an example of one such policy. Equally, it may also explain why during the last thirteen years or so the 'Big Push to Overcome the Apartheid Legacy' has not been big enough.

Marginalisation and powerlessness are typical examples of structural forms of oppression that are contrary to the principles of social justice. Marginalisation occurs when an entire category of people is excluded from meaningful participation in social life (Niewehuis, 2010, p.200). This denotes that social justice necessitates inclusion. The notions of social exclusion and inclusion emphasise the extent to which the benefits of development, social interaction networks, and political participation are inequitably distributed (Ocampo, 2004, p.33). Social exclusion analysis may also be perceived as a way of examining how and why individuals and groups fail to have access to or benefit from the possibilities offered by societies and economies (Oakley, 2004, p.97).

At a theoretical level, the BBBEE policy seeks to maximise every citizen's utility in the country since social welfare is maximized when complete equality of the distribution of the total income is achieved. The argument is that a greater degree of equality is achieved when there is recognition that individual utility depends on the individual's real income as well as on other people's income as well (Podder, 1998, p.1246). Moreover, the BBBEE policy framework also takes into account the fact that its implementation in one section of the economy should not be to the detriment to any other section. The Department of Trade and Industry $(2007$, p.9) cautions that when different charters gazetted as Codes of Good Practice 'are applied to different entities presenting their BEE credentials, none of the entities will be unfairly disadvantaged over the other because of the application of a more stringent industry charter.' Therefore, one of the underlying principles of the BBBEE policy framework is that of Pareto improvement in which the policy seeks to improve previously disadvantaged people without making the previously advantaged worse-off.

There is no doubt that the principle of social justice provides justification for the conceptualization of the BBBEE policy framework in South Africa. Yet Young $(2000$, p.25) posits that social justice requires the establishment of institutional and other structural conditions for promoting self-determination and self-development of all members of society. Omaro (2007, p.1) describes the state capacity as the ability of the state to act authoritatively to transform the structural basis of the economy in order to achieve economic growth, reduce poverty, income and wealth inequalities. Indeed, without the establishment of proper institutional and structural conditions as well as the ability to act authoritatively on the part of government in implementing the BBBEE policy framework, that prospect of achieving the social justice objectives of the policy framework may well prove to be a pipe dream.

\section{The BBBEE Policy Implementation}

The BBBEE policy and its implementation remains a hotly contested debate among analysts, researchers, policy makers, politicians, and the civil society (Levin, 2011, p.253). In support, Andreasson (2010, p.33) impresses upon the fact that the 'widening bifurcation of debates on socio-economic development and transformation is indicative of the increasing societal rift. Acemoglu, Gelb, and Robinson $(2001$, p.4) argue that while the argument that BEE is theoretically justifiable and compelling, the policy should be transitory rather than permanent and that the government should have already 
committed itself to a clear timetable to phase out the policy.

A common conceptualization among analysts and scholars is that implementation remains a 'complex, dynamic, multilevel, multi-actor process influenced by the content and the context of the policy being implemented' (Brynard, 2000, p.174). For instance, implementers of policies often find that they have to interpret policies and discern their meaning in terms of their day-to-day business since policies generally do not convey sufficient contexts. In addition, the lack of skill or knowledge base necessary to implement the policy often compounds the problem (Hill, 2003, p.268). Individually or collectively, these challenges are likely to result in policy failure.

In general, policy failure occurs either because a policy is not well formulated or its implementation is simply unsuccessful. Hunter and Marks (2002, p.5) opine that policy implementation is unsuccessful when 'a policy is carried out in full and external circumstances are not unfavourable yet the policy fails to produce the intended results or outcomes.' Hunter and Marks $(2002$, p.6) further assert that the likelihood of a successful implementation is increased if potential constraints of implementation are factored in at the policy design stage. The authors also point out that a good understanding of the constraints, even after the beginning of the implementation will help in making the necessary modifications to the implementation process before it is too late.

The complexities involving policy implementation necessitate that the monitoring of these programs should not be delayed after commencement the actual implementation. This notion is congruent with Cloete's (2000, p.215) assertion that during policy implementation, a need exists to put in place some monitoring mechanism which ensures that there is progress towards the achievement of objectives and in enhancing the quality and quantity of outputs. Brynard (2000, p.179) characterized policy in terms of content as distributive, regulatory or redistributive. The nature and objectives of the BBBEE policy makes it a redistributive policy since in terms of the Act, its objectives include the promotion of economic transformation in order to enable meaningful participation of black people in the economy and the achievement of sustainable change in the racial composition of ownership and management structures and in the skilled occupations of existing and new enterprises.

\section{The BBBEE Policy and the Self-Regulatory Power of the Market}

Ordinarily, the policy development process allows policymakers to develop or formulate a policy while the implementers execute the policy. Oftentimes, these roles are fulfilled by people and in most cases, the policymakers have some control by virtue of organizational relationship over the implementers. Hill $(2003$, p.35) refers to such implementers as 'streetlevel bureaucrats'. On the other hand, there are policy processes in which policymakers have no direct organizational control over people or organizations expected to implement the policy. The implementation of the BBBEE policy is a case in point. The government has formulated the BBBEE policy while the market is expected to implement it. There are no statutory mechanisms that enforce its implementation. This suggests that there are no 'street-level bureaucrats' or 'frontline implementers'. Neither are there 'command and control mechanisms' to ensure that the BBBEE policy framework is effectively implemented.

In its current form, the BBBEE the policy is left to the 'self-regulatory power of the market' which according to the neoliberal model is the only mechanism that can bring society to its desired state and at the same time capable of bringing about economic effectiveness. The self-regulation power of the market is at the epicentre of the policy. The policy is based on the rationale that to the extent that the company contributes to the BBBEE imperatives in terms of the generic scorecard, it places itself in a good position to benefit from economic opportunities flowing from the value chain. As the biggest single buyer of goods and services, the government creates a strong value chain for businesses. The underlying assumption is that the more businesses contribute to BBBEE imperatives the more likely they will benefit from the economic opportunities flowing from the government's strong value chain. Furthermore, the more a company contributes to BEE imperative the higher its BEE status and BEE procurement recognition level will be, thereby facilitating access to the economy (DTI, 2007).

Rhodes (1996, p.653) identifies six separate uses of governance as the minimal state, corporate governance, the new public management, 'good governance', as a socio-cybernetic system, and as self-organizing networks. These applications of governance espouse the distinct character and role or lack of played by the state. The socio-cybernetic and self-organising networks governance systems seem to be aptly characteristic of the BBBEE policy framework. Sociocybernetic system is characterised by the centre or government formulating a policy area without imposing it on the multiple independent actors. Under this system, none of the actors including the government has full knowledge or resources to make the policy functional. In essence, the role of the government is mainly to create an enabling environment for socio-political interactions to occur. Since the government is not a dominant player in this relationship, 
this phenomenon may be described as 'governance without government' Rhodes (1996, p.657). Davies (2002, p.301) acknowledges that if partnerships (a mixture of market, hierarchy and network) as a mode of governance are to be understood, more comparative studies would have to be conducted.

Rhodes (1996, p.658) describes the self-organising networks as comprising organizations that need to exchange resources to achieve their objectives, among other things. The author concludes that 'the network form of governance highlights reputation, trust, reciprocity and mutual interdependence.' These networks are self-organising in the sense that not even the government has enough power to control the actors within the network. Rhodes $(1996, p .660)$ further contends that those networks which are not accountable to the state, 'resist government steering and that they would rather develop their own policies and mould their environment'. Stiglitz (2012, p xiii) states that markets, by themselves, even when they are stable, often lead to high levels of inequality.

Insofar as the BBBEE policy framework is concerned, the South African government has adopted a sociocybernetic system in which the role of government is the creation of an enabling environment as well as availing incentives for companies that comply with the BBBEE imperatives. Concurrently, the policy framework fits the selforganising networks in the sense that even though there are now Codes of Good Practice, the government still encourages industry-based charters which are self-organizing and are not accountable to the state.

These governance systems which characterize the BBBEE policy framework and its implementation run contrary to the South African government assertion and aspiration of being a developmental state (Kondlo \& Maserumule (2010).

\section{The Role of the Developmental State}

Milward and Provan $(2000$, p.360) sustain that in common usage, government refers to the formal institutions of the state and their monopoly of legitimate coercive power. The scholars describe governance as a more inclusive term that is concerned with creating the conditions for ordered rule and collective action, often including agents in the private and nonprofit sectors as well as within the public sector. On the other hand, Jordan, Wurzel and Zito (2005, p.481) suggest that in political science literature, government is associated with the traditional form of regulation, bureaucracy, and legislation whereas governance is characterised by the growing use of non-regulatory policy instruments often implemented by non-state actors, sometimes in conjunction with state actors while at other times also independently.

A developmental state is characterised by a 'developmentalist' approach that supports the achievement of the developmental agenda of the state with a rapidly growing economy and social development as primary objectives (Mkhandawire, 2010, p.2; Vasoo \& Lee, 2001, p.1). Furthermore, successful developmental states are characterized by strong state structures that are able to formulate and implement policies (Mkhandawire, 1998, p.290) and facilitate redistribution in shaping the country's economic dimension (Natrass \& Seekings (2002, p.215). It should be noted though, that economic growth on its own will not support the facilitation of redistribution (Edigheji, 2007, p.11).

Interestingly, before the ANC became the ruling party, it developed and adopted the Reconstruction and Development Programme (RDP) which came to be known as the base document within the ANC. The RDP was used as the ANC election manifesto and in 1994 became a White Paper the White Paper on the Reconstruction and Development Programme (RSA, 1994) and the White Paper on the Developmental Social Welfare (RSA, 1997) sought to foster more just and equal society. In 1996, the RDP was replaced by the Growth, Employment and Redistribution (GEAR) macroeconomic strategy (Hisrch, 2005). Part of the fundamental difference between the RDP and GEAR is that the former had the state as the centre of development whilst the latter focused on the market as the driver for economic growth (De Wet, 2010, p.71; Edigheji, 2007, p.10).

The state performs the allocation, distribution, and stabilisation functions in the economy and uses its fiscal policy to do so (Biggs, 1997, p.191). When the South African government adopted GEAR as its macroeconomic strategy, the real focus of the fiscal policy at the time was the deficit-reduction programme (Roux, 2004). Failure by the market to allocate and distribute resources equitably should necessitate the state to intervene in the economy by allocating and distributing resources in a manner consistent with overall government policy. This is evident from the concession by Chabane (2010, p.1) that nearly two decades into the democracy, South Africa still faces significant challenges of inequality. The BBBEE policy is meant to reduce the deep inequalities inherited from the past. Such an unequal distribution of resources currently exists in South Africa as the country is characterised by the side by side coexistence of poverty and extraordinary opulence (Mbeki 2009). In this regard, Jara (2012, p.31) observes that the government's embrace of and consistent adherence to neoliberal economic policy continues to concentrate economic resources, wealth and power in the hands of the elite.

Interestingly, Potucek and Vass $(2003$, p.8) refer to the 'inequality reducing model', which is premised on the 
assumption of diminishing marginal utility set against growing wealth. In effect, the assumption postulates that the richer people become the less marginal utility they receive for the same amount of money while the same unit of wealth would make the poor to be significantly better-off. The principle behind this model is that 'the more equally a given amount of resources are distributed, the higher the value of the function of social happiness will be.' The model also stresses that instead of leaving the redistribution of resources and wealth to the market only, it is imperative for the government to intervene (Potucek \& Vass, 2003, p.8). The model for reducing inequality requires an interventionist state. Governments constantly face the dilemma of either intervening to shape the economic dynamics of the country or to adopt a laissezfare attitude of allowing the situation to correct itself accordingly. This is the dilemma that the South African government is currently facing.

Further, the inequality reducing model is helpful in shedding some light into understanding whether the market is the best mechanism through which to implement the BBBEE policy framework. Proponents of this model argue that by its nature, the market is insensitive to the needs of individuals such that 'some people are endowed with large resources while others lack the resources to satisfy their basic needs' (Potucek \& Vass, 2003, p.8). Podder (1998, p.1245) also maintains that as a basic value judgment, equity never features explicitly in neo-classical economics, a consideration that a social policy-maker cannot afford to avoid explicitly.

Goodin $(1995$, p.35) maintains that 'where discharging a moral obligation is the business of nobody in particular, the claim that each person should be allowed to his or her own business without interference does not apply'. Social justice also entails the equal redistribution of socio-economic amenities (Gerwitz \& Gribb, 2002:499) while emphasizing the role of the state in ensuring this redistribution (Gale, 2000:268). In support, Young (2000, p.189) claims that if left to themselves, the organization and consequences of the market impedes the self-development of many people. This seems to point to the need for more regulation from government's side. In fact, Acemoglu, Gleb and Robinson (2007:12) caution that the presence of market failures can lead the initial conditions of Apartheid to reproduce themselves over time, even after the laws and structures which created them have been changed.

Young (2000, p.185) argues that promoting social justice requires attending to issues of self-development as well as self-determination and that if promoting social justice means that societies should aim to make conditions for selfdevelopment available for everyone, as it should be, then the endemic consequences of the free market system ought to be corrected. The author further argues that if self-development for everyone is to take place, the state is the most important means of regulating and directing economic life since only the state and its institutions have the capacity to limit the power of large enterprises and facilitate the use of that private power for the collective well-being (Young, 2000, p.186).

Self-development means the ability to actively engage and grow. Enterprises afford people opportunities of engagement and growth, and the more enterprises the economy can develop the more opportunities of engagement and growth can be afforded. Phelps $(2008, p .8)$ concurs that the entry of those that are marginalized and disadvantaged into the mainstream economy enhances the diversity of the participants, thereby opening up new and added sources of innovation. Amini (2004, p.375) upholds that development involves 'creating an economic and political environment in which people can expand their capability and choices and that when growth and progress are not connected, the unemployed and workers in insecure and poorly-paid jobs feel alienated from the growth of their national economy'. Besides offering economic benefits, enterprise development also provides social and political benefits to society.

In this regard, Amini (2004, pp.379-380) opines that small enterprises are an effective means of political participation and decentralisation and therefore the generation of democracy. The author throws spotlight on the fact that 'small businesses provide a better environment for cooperation and effective means for women's involvement in the socio-economic activities'. Jack and Harris $(2007$, p.320) also hint that enterprise development will most likely 'result is long-term sustainability of black economic participation'. Stimulation of small businesses may therefore be a viable option for most developing economies.

\section{Concluding Remarks}

The philosophy underpinning the current BBBEE policy framework largely presupposes that the market will act rationally enough to follow the aspirations of government. These aspirations include a more equal distribution of income and wealth and the facilitation of the movement of black people from the periphery towards the centre of economic activities. The government would be silly to trust the market, known for its distortions, to implement a policy which is meant to bring about a socially just economic system in South Africa.

The paper acknowledged that policy development and implementation of policy is a complex exercise, let alone 
one the one whose successful implementation depends on the market. Part of the argument raised was that the implementation difficulties of the BBBEE policy have to do with the nature of equality emphasised or perceived to be emphasised by the Constitution, namely equality of opportunity. While equality of opportunity is necessary, it is by no means sufficient to bring about conditions of social justice within the economic landscape of South Africa. On the contrary equality of condition should rather determine the values that need to inform the path towards conditions of social justice.

That the implementation of BBBEE policy hinges on the self-regulatory power of the market is possibly the biggest flaw - the Achilles heel of the policy framework. The paper pointed to the silliness of government to leave the matters of social justice and equality in the hands of the insensitive market. The overreliance of the sate on the market may be tantamount to the abdication of its allocation and (re)distribution functions in the economy. Besides, the markets fail from time to time.

The autonomous self-organising networks tend to resist the idea of government steering and regulation and prefer to develop their own policies as well as to mould their environment without government intervention. The self-regulatory power of the market increases and the self-organizing networks deepen where there is a lack of capacity on the part of the state to lead effective economic transformation. It would be expected of a government that aspires to be a developmental state to be more interventionist in the implementation of BBBEE policy framework rather than leaving it to the mercy of unpredictable market forces and their related dynamics. Economic transformation and development in South Africa can only be achieved when government plays a more significant role in terms of regulation.

In view of the above, the paper makes the following recommendations. First, the government needs to focus its economic transformation agenda around the reduction of inequality in South Africa. As a market-based instrument, the BBBEE policy may, in fact, lead to an unintended consequence of more inequality. The problem of inequality is fast becoming a 'New HIVI AIDS scourge' globally including the United States, Britain, and England among other countries. In view of this, South Africa needs a strategy which is more robust than the current BBBEE policy framework, which has in reality become a social accounting system; rather one that is designed to tackle the scourge of inequality than BBBEE. The elements of the BBBEE scorecard such as employment equity, skills development and preferential should be enhanced and be pursued as existing individual pieces of legislation. Once these pieces of legislation are made more effective, the BBBEE framework can be replaced by a national strategy targeted at reducing inequality.

Second, there is a need of a coordinated national strategy and plan on enterprise development in South Africa. The political language needs to change from job creation to enterprise creation as jobs and employment do not exist independent of existing and new enterprises. While the recommended national strategy and plan on enterprise needs to include all entrepreneurs, current and prospective, there could be instruments and incentives designed with a bias for previously disadvantaged people, women, youth, people with disability, etc.

Third and perhaps most important, the government needs to make education as a focal point for economic transformation and development. The former president Nelson Mandela has been quoted as saying: "Education is the most powerful tool in transforming society'. Brazil, a country which has had one of the highest levels of inequality, is a case in point. The massive increases in education expenditure under President Enrique Cardoso saw inequality reduced, growth increased, and society become more stable. At this point, education should be treated as the key driver to economic transformation and development. Without elevating education to this level, all other efforts for economic transformation and development may be short-lived and short-sighted.

\section{References}

Acemoglu, D., Gelb, S. \& Robinson, J. 2001. Progress report and notes on Black Economic Empowerment and economic performance in South Africa.

Amini, A. 2004. The distributional role of small business in development. International Journal of Social Economics, 31 (4), pp. 370-383. Andreasson, S. 2010. Africa's development impasse: rethinking the political economy of transformation. London: Zed Books.

Biggs, M. 1997. Fiscal Policy in South Africa. In N. Nicoli (eds) Macroeconomics: Theory and policy in South Africa. Cape Town: David Philip.

Brynard, 2000. Policy Implementation. In F. Cloete \& H. Wissink (eds.) Improving Public Policy. Pretoria: Van Schaik.

Bundy, C. 1982. The emergence and decline of a South African peasantry. In M Murray (ed), South African Capitalism and Black Political Opposition, Cambridge: Schenkman Publishing.

Brighouse, H. 2002. Egalitarean liberalism and justice in education. USA: Blackwell Publishers.

Davies, J.S. 2002. The governance of urban regeneration: A critique of the 'governing without government' thesis. Public Administration, 80 (2), pp.301-322.

Cloete, F. 2000. Policy evaluation or assessment. In F. Cloete \& H. Wissink, Improving Public Policy. Pretoria: Van Schaik. 
Department of Trade and Industry. 2007. Broad-based Black Economic Empowerment Act: The Codes of Good Practice. Interpretive Guide. Republic of South Africa

Easterly, W. 2002. The Elusive Quest for Growth: Economists' Adventures and Misadventures in the Tropics. Cambridge: MIT Press.

Edigheji, O. 2007. The emerging South African democratic developmental state and the people's contract. Research report 108. Johannesburg: Centre for Policy Studies, 'State series'.

Feinstein, C. 2005. An economic history of South Africa: conquest, discrimination and development, Cambridge: Cambridge University Press.

Gerwitz, S. \& Gribb, A. 2002. Plural conceptions of social justice: implications for policy sociology. Journal of Education Policy, 17, pp. 499-599.

Goodin, R. 1995. The state as a moral agent. In Utilitarianism as a public philosophy. Cambridge: Cambridge Press.

Hill, H.C. 2003. Understanding implementation: street-level bureaucrats' resources for reform. Journal of Public Administration Research and Theory, 13 (3), pp. 265-282.

Hirsch, D. 2005. Season of hope: Economic reform under Mandela and Mbeki. Scottsville: University of Kwazulu-Natal Press.

Hunter, D.J. \& Marks, L. 2002. Decision-making Processes for Effective Policy Implementation. Unpublished Paper.

Jack, V. \& Harris, K. 2007. Broad-based BEE: The complete guide. Northcliff: Frontrunner Publishing (Pty) Ltd.

Jara, M. 2012. Mobilise the masses for democracy: South Africa needs a well-run campaign to steer it away from the capitalist-loving ANC's course. Mail \& Guardian, November 9-15, p.31.

Jordan, A., Wurzel, R.K.W. \& Zito, A. 2005. The rise of 'new' policy instruments in comparative perspective: Has governance eclipsed government? Political Studies, 53, pp.477-496.

Kondlo, K.M. \& Maserumule, M.H. (eds). 2010. The Zuma Administration: critical challenges. Cape Town: HSRC Press.

Levin, R. M. 2011. Broad-based empowerment or dependent accumulation? The state and development in South Africa. In D. Plaatjies (eds), Future inheritance: building state capacity in democratic South Africa. Auckland Park: Jacan Media (Pty) Ltd.

Mbeki, M. 2009. Architects of poverty: why African capitalism needs changing. Johannesburg: Picador Africa.

McKinley, D. 1998. "The Problem with Union Investment Funds". Debate 4 Voices from the South African Left 2 (1): 102-107.

Milward, H.B. \& Provan, K.G. 2000. Governing the hollow state. Journal of Public Administration Research and Theory,10(2),pp.359-379

Mkandawire, T. 2001. Thinking about developmental states in Africa. Cambridge Journal of Economics. Oxford University Press, 25 (3). pp.289-314.

Natrass, N. \& Seekings, J. 2002. A divided nation: Distribution in post-apartgeid south Africa. Daedalus, 130 (45-70).

Nieuwenhuis, J. 2005. From equality of opportunity to equality of treatment as a value-based concern in education. In C Russo, JL Beckman, and JD Jansen (eds) Equal educational opportunities: comparative perspectives in education. Pretoria: Van Schaik.

Oakley, P. 2004. Europeans origins of social exclusion: application to developing countries. In M. Buvinic, J Mazza \& R Deutsche, Social inclusion and economic development in Latin America. Inter-American Development Bank: Johns Hopkins University Press.

Ocampo, J.A. 2004. Economic development and social inclusion. In M. Buvinic, J Mazza \& R Deutsche, Social inclusion and economic development in Latin America. Inter-American Development Bank: Johns Hopkins University Press.

Omano, E. 2007. Affirmative action and state capacity in a democratic South Africa. Johannesburg: Centre for Policy Studies.

Phelps, E.S. 2008. Dynamism and inclusion: What? Why? How? Inaugural lecture at Phelps Chair, School of Law, University of Buenos Aires, May 20.

Podder, N. 1998. The implications of economic inequality for social welfare and social conflict. International Journal of Social Economics, 25 (6/7/8), pp. 1244-1254.

Potucek, M. \& Vass, L. 2003. Dimensions of Public Policy: Values, Processes, Implementation and Results. In M. Potucek, L.T. Leloup, G. Genei \& L. Varadi (eds.) Public Policy in CEE: Theories, Methods, Practices. Bratislava: NISPAcee.

Rawls, J. 1958. Justice as fairness. Philosophical Review, 67(2), pp163-193.

Republic of South Africa (RSA). 1996. The Constitution of the Republic of South Africa, 1996 (Act 108 of 1996). Pretoria: Government Printers.

Republic of South Africa (RSA). 1994. White Paper for Reconstruction and Development. November, Pretoria: Government Printer.

Republic of South Africa (RSA). 1997. White Paper for Social Welfare, August. Pretoria: Government Printer.

Republic of South Africa (RSA). 2001. Government of the Republic of South Africa and Others v Grootboom and Others 2001 (1) SA 46 (Constitutional Court).

Rhodes, R.A.W. 1996. The New Governance: Governing without Government. Political Studies, XLIV, pp.652-667.

Roux, A. 2004. Getting into Gear. In P. Hall (eds) Manuel, markets and mone: Essays in appraisal. Cape Town: Double Storey Books.

Rubushe, M. 2009. Trade union investment schemes: a blemish on the social movement unionism outlook of South African unions? Unpublished Master's thesis. Rhodes University.

Schaar, J.J. 1997. Equality of opportunity and beyond. In L Pojman \& R Westmoreland (eds), Equality: selected readings. Oxford: Oxford University Press.

Stiglitz, J.E. 2012. The price of inequality - How today's divided society endangers our future. Manchester: Penguin Books Limited.

Stewart, F. 2001. Horizontal Inequalities: A Neglected Dimension of Development. Paper presented at the Annual Development Lecture, United Nations University World Institute for Development Economics Research, May 25-26, Helsinki, Finland.

Vasoo, S. \& Lee, J. 2001. Singapore: Social development, housing and the central provident fund. International Journal of Social Welfare. 10 (276-283).

Young, I.M. 2000. Inclusion and democracy. New York: Oxford University Press. 